\title{
Article
}

\section{Operating Limits for Ammonia Fuel Spark-Ignition Engine}

\author{
Christine Mounaïm-Rousselle ${ }^{1, *}$, Pierre Bréquigny ${ }^{1}$, Clément Dumand $^{2}$ and Sébastien Houillé ${ }^{2}$ \\ 1 PRISME, University Orléans, INSA-CVL, F-45072 Orléans, France; pierre.brequigny@univ-orleans.fr \\ 2 Stellantis-PSA Centre Technique de Vélizy, Vélizy-Villlacoublay, F-78140 Vélizy-Villacoublay, France; \\ clement.dumand@stellantis.com (C.D.); sebastien.houille@stellantis.com (S.H.) \\ * Correspondence: christine.rousselle@univ-orleans.fr
}

Citation: Mounaïm-Rousselle, C.; Bréquigny, P.; Dumand, C.; Houillé, S. Operating Limits for Ammonia Fuel Spark-Ignition Engine. Energies 2021, 14, 4141. https://doi.org/10.3390/ en14144141

Academic Editor: Giovanni Cinti

Received: 10 June 2021

Accepted: 6 July 2021

Published: 9 July 2021

Publisher's Note: MDPI stays neutral with regard to jurisdictional claims in published maps and institutional affiliations.

Copyright: (C) 2021 by the authors. Licensee MDPI, Basel, Switzerland. This article is an open access article distributed under the terms and conditions of the Creative Commons Attribution (CC BY) license (https:/ / creativecommons.org/licenses/by/ $4.0 /)$.

\begin{abstract}
The objective of this paper is to provide new data about the possibility of using ammonia as a carbon-free fuel in a spark-ignition engine. A current GDI PSA engine (Compression Ratio 10.5:1) was chosen in order to update the results available in the literature mainly obtained in the CFR engine. Particular attention was paid to determine the lowest possible load limit when the engine is supplied with pure ammonia or a small amount of $\mathrm{H}_{2}$, depending on engine speed, in order to highlight the limitation during cold start conditions. It can be concluded that this engine can run stably in most of these operating conditions with less than $10 \% \mathrm{H}_{2}$ (of the total fuel volume) added to $\mathrm{NH}_{3}$. Measurements of exhaust pollutants, and in particular $\mathrm{NOx}$, have made it possible to evaluate the possibility of diluting the intake gases and its limitation during combustion with pure $\mathrm{H}_{2}$ under slightly supercharged conditions. In conclusion, the $10 \%$ dilution limit allows a reduction of up to $40 \%$ in NOx while guaranteeing stable operation.
\end{abstract}

Keywords: ammonia; SI engine; pollutant; performance

\section{Introduction}

The 2015 Paris Agreement (https://unfccc.int/sites/default/files/english_paris_ agreement.pdf/ accessed on 7 July 2021) aiming at mitigating greenhouse gases requires a global transition from fossil to renewable resources use in the next decades. Nowadays, the main energy sources, such as fossil fuels, should be replaced by renewable energy sources, together with increased electrification of many usages. Alternative fuels are, therefore, widely considered as important energy carriers because they are particularly adapted for specific hard-to-electrify end-uses, such as high-temperature heat, long-distance mobility, or even for mid- and long-term energy storage. According to the International Energy Agency (IEA) (https:/ / iea.blob.core.windows.net/assets/9e3a3493-b9a6-4b7d-b499-7ca4 8e357561/The_Future_of_Hydrogen.pdf / accessed on 7 July 2021), 'green' hydrogen will play a key role in the world's transition to a sustainable energy future as it is one of the most promising and clean energy carriers, both for transportation and power generation. However, even using the best available technologies, its density is too low for it to be easily transported and stored with acceptable safety and at a reasonable cost. Among other renewable fuels, Ammonia $\left(\mathrm{NH}_{3}\right)$ is currently receiving an increased interest as a potential renewable carbon-free energy carrier [1-3]. It is both considered as a fuel for direct use in a combustion system or fuel cell, or as an efficient hydrogen carrier $(17.8 \%$ hydrogen content by mass) when it is decomposed. Although ammonia use as an internal combustion engine fuel has been considered since many decades, its deployment was first limited by the competition with hydrocarbon fuels in terms of availability, handling ease, and safety, as well as energy density and combustion properties. Indeed, it is a toxic chemical with difficult flammability and very low combustion intensity, illustrated by its narrow flammability limits (FL) and low Laminar Burning Velocity (LBV) in Table 1 ((data from $[2,4,5]$, respectively. Nonetheless, today's context on global warming is making fossil fuels undesired due to their unacceptable environmental impact, and ammonia exhibits 
many advantages. First, due to the huge development of renewables energies and water electrolysis as one storage solution, 'green' ammonia could be produced economically without any carbon emissions, and as its combustion releases mainly water and nitrogen. Moreover, as displayed in Table 1, ammonia can be stored as a liquid under mild pressure conditions at ambient temperature, thus ensuring a comparable energy density with other fuels, especially regarding its competitive Lower Heating Value (LHV). A life cycle analysis provided by Bicer and Dincer [6] showed that greenhouse gas emissions could be reduced by almost a factor three by using ammonia-fueled vehicles instead of gasoline vehicles. Even though there is no transport fleet currently running with ammonia as fuel, using it as an alternative to fossil fuels for transportation vehicles was already considered several decades ago. The first famous example is the bus fleet operated in Belgium during World War II caused by the limited availability of Diesel fuel [7]. It was also the birth of the first dual-fuel engine: coal gas (composed of $50 \% \mathrm{H}_{2}$ ) was directly injected into the combustion chamber filled with ammonia. In the mid-60s, several studies [8-14] focused on the possibility of using ammonia as fuel in thermal engines, providing first recommendations regarding the chemical compatibility of ammonia because of its corrosiveness to copper, copper alloys, nickel, and even some plastics. The two classical engine architectures were considered in these studies, namely Spark-Ignition (SI) and Compression Ignition (CI). Although most projects currently concern CI engines [15], the low auto-ignition ability and high octane rating (Table 1 ) of ammonia suggests a more suitable use in SI engines. The energy content of ammonia introduced for a stoichiometric mixture with air is higher than that of gasoline, but fuel consumption is doubled in the case of neat ammonia. However, its low flame speed and narrow flammability limits can lead to incomplete combustion in SI engines. To counterbalance, ignition could be promoted by a more reactive fuel, as $\mathrm{H}_{2}$ or gasoline type fuel and the in-cylinder temperature can be increased by a higher compression ratio (CR) or supercharged conditions without any risk of knocking.

Table 1. Ammonia properties and comparison with other fuels at $300 \mathrm{~K}$ and $0.1 \mathrm{MPa}$, unless stated otherwise.

\begin{tabular}{|c|c|c|c|c|c|}
\hline Species & Ammonia & Methanol & Hydrogen & Methane & Gasoline \\
\hline Formula & $\mathrm{NH}_{3}$ & $\mathrm{CH}_{3} \mathrm{OH}$ & $\mathrm{H}_{2}$ & $\mathrm{CH}_{4}$ & - \\
\hline Storage & Liquid & Liquid & Compressed & Compressed & Liquid \\
\hline Storage temperature (K) & 300 & 300 & 300 & 300 & 300 \\
\hline Storage pressure (MPa) & 1.1 & 0.1 & 70 & 25 & 0.1 \\
\hline $\begin{array}{c}\text { density @ storage conditions } \\
\left(\mathrm{kg} \cdot \mathrm{m}^{-3}\right)\end{array}$ & 600 & 784.6 & 39.1 & 187 & $\sim 740$ \\
\hline FL in air (vol.\%) & $15-28$ & $6.7-36$ & $4.7-75$ & $5-15$ & $0.6-8$ \\
\hline $\begin{array}{l}\text { LBV @ stoichiometry } \\
\left(\mathrm{m} \cdot \mathrm{s}^{-1}\right)\end{array}$ & 0.07 & 0.36 & 3.51 & 0.38 & 0.58 \\
\hline Auto-ignition T (K) & 930 & 712 & $773-850$ & 859 & 503 \\
\hline Research Octane Number & 130 & 119 & $>100$ & 120 & $90-98$ \\
\hline LHV (MJ/kg) & 18.8 & 19.9 & 120 & 50 & 44.5 \\
\hline
\end{tabular}

A recent review [16] reported only 16 studies investigating the use of ammonia fuel in spark-ignition engine. About half of them were conducted in CFR engine with CR ranging from 6.1 to 10 , which is representative of current vehicles $[6,10,17-21]$. The other half were conducted with modern single cylinder engine [22-25] or multi-cylinder engine [26,27]. Among those studies, only two investigated higher CR, i.e., about 14:1 [6,22]. From this review, it is striking to realize that only a few have explored the feasibility of running an SI engine with ammonia only. At this state it can be concluded that pure ammonia is possible mainly at full load operation, as underlined in [22] and recently confirmed by Lhuillier et al. [24,25]. To improve the combustion process, the best carbon-free promoter 
is hydrogen but also due to its combustion velocity and wide flammability range. In [16], Mounaïm-Rousselle and Brequigny concluded from previous studies $[6,23-25,28]$ that with conventional CR (about 10:1), only small quantities of hydrogen (around 5 to 10\%) are necessary to ensure stable operation and best efficiencies. Those small quantities can even be obtained by the means of an thermal converter to dissociate on-board ammonia into $\mathrm{H}_{2}$ and $\mathrm{N}_{2}[22,29]$. Yet, only one study evoked the $\mathrm{H}_{2}$ requirement at idle speed, which seems to be so important that it cannot be provided with such a converter [28].

Regarding the pollutant emissions caused by the use of ammonia fuel, the issue is not trivial and requires in-depth studies before being able to propose optimized solutions accordingly to the best operating mode to deal with the problem of NOx, perhaps $\mathrm{N}_{2} \mathrm{O}$ but also $\mathrm{NH}_{3}$ or even $\mathrm{H}_{2}$. Without any after-treatment device, it appears that:

- Lean operation leads to high $\mathrm{NOx}$ (higher than with gasoline) but low unburnt $\mathrm{NH}_{3}$

- Rich operation leads to low $\mathrm{NOx}$ but too high unburnt $\mathrm{NH}_{3}$, unacceptable due to the smell and toxicity

- Increasing $\mathrm{H}_{2}$ quantity at the intake leads to a slightly higher NOx level, very low unburnt $\mathrm{NH}_{3}$ (due to a better combustion efficiency) but with some $\mathrm{H}_{2}$ content at the exhaust.

At this point, the optimization of the use of ammonia as fuel suffers from the limited data available on the performance of ammonia-fueled vehicles. Therefore, in order to increase the knowledge on ammonia fueled SI engine, the present paper will provide new data:

- First, as a function of different engine speeds, with small $\mathrm{H}_{2}$ quantities at atmospheric intake pressure

- Second to determine the lowest acceptable intake pressure, i.e., load conditions,

- And lastly, on a first evaluation of the possible dilution to limit pollutants for one particular condition (slight turbocharged conditions, fixed engine speed of $2000 \mathrm{rpm}$ ).

\section{Experimental Methods}

\subsection{Experimental Set-Up}

Engine experiments were conducted in a modern 4-cylinder 4-stroke Gasoline Direct Injection-SI EP6 PSA engine, modified to become an indirect injection single-cylinder engine by filling only 1 of 4 cylinders as fully described in [21]. The engine specifications are presented in Table 2.

Table 2. Engine specifications.

\begin{tabular}{|c|c|}
\hline Displaced Volume & $399.5 \mathrm{~cm}^{3}$ \\
\hline Stroke & $85.8 \mathrm{~mm}$ \\
\hline Bore & $77 \mathrm{~mm}$ \\
\hline Connecting rod length & $138.5 \mathrm{~mm}$ \\
\hline Compression ratio & $10.5: 1$ \\
\hline Number of valves & 4 \\
\hline
\end{tabular}

The engine was driven by an electric motor at a fixed engine speed varied from 650 to $2000 \mathrm{rpm}$. The main shaft was equipped with an optical encoder for angular position monitoring with a 0.1 Crank Angle Degree (CAD) resolution. A water-cooled AVL piezoelectric pressure transducer with a $0.1 \mathrm{CAD}$ resolution and a measuring range of 0-25 MPa provided in-cylinder pressure measurements. Engine intake and exhaust temperature and pressure were monitored using K-type thermocouples and piezo-resistive absolute pressure transducers. The absolute cylinder pressure was obtained by equalizing it with the mean absolute intake pressure, $P_{i n}$, at 20 CAD after inlet valve opening. The spark plug device was the original one with a time discharge set to $2 \mathrm{~ms}$. 
Ammonia, hydrogen, and air gaseous flows were measured and controlled using Brooks thermal mass flowmeters with $\pm 0.7 \%$ accuracy. They were preheated to the intake temperature of $323 \mathrm{~K}$ and premixed in an intake plenum before injection. A scheme of the experimental setup is shown in Figure 1.

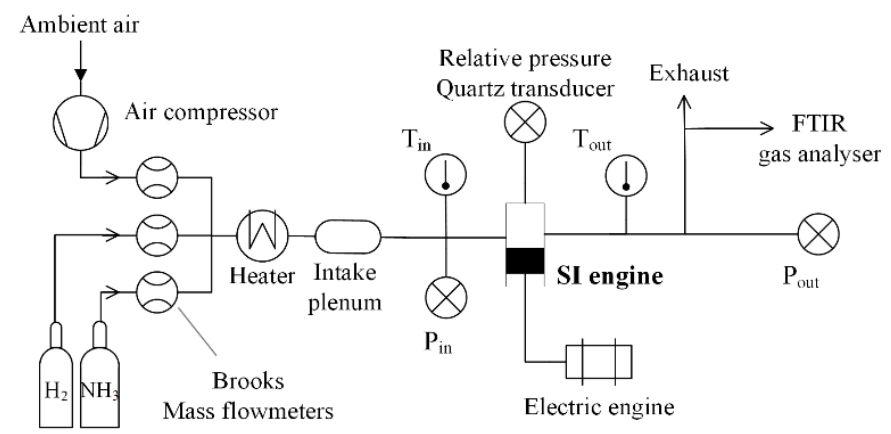

Figure 1. Layout of the experimental setup.

The wet exhaust gases were analyzed using a Gasmet Fourier Transform Infrared (FTIR) spectrometer to assess $\mathrm{H}_{2} \mathrm{O}, \mathrm{NO}, \mathrm{NO}_{2}, \mathrm{~N}_{2} \mathrm{O}$, and $\mathrm{NH}_{3}$ concentrations. To obtain simultaneous quantitative measurement of many gaseous species with a good time resolution and accuracy, the interferences between the species of interest were correctly identified and considered in the analysis settings. The analysis ranges and uncertainty estimation can be found in previous work [30]. Please note that error bars were not plotted consistently in order to improve readability. In addition, analyzers for $\mathrm{H}_{2}$ by thermal conductivity and $\mathrm{O}_{2}$ by paramagnetic (ADEV) were used on a dry exhaust gas sample (without $\mathrm{H}_{2} \mathrm{O}$ and $\mathrm{NH}_{3}$ ). The water vapor measurement conducted with the FTIR analyzer was used for wet correction. The accuracy of the $\mathrm{H}_{2}$ and $\mathrm{O}_{2}$ analyzers was $\pm 1 \%$ (range $0-20 \% \mathrm{H}_{2}, 0-21 \% \mathrm{O}_{2}$ ).

\subsection{Investigated Conditions}

The global stoichiometric reaction of $\mathrm{NH}_{3} / \mathrm{H}_{2}$ /air complete combustion was, where $x_{\mathrm{H}_{2}}$ is the hydrogen molar fraction in the fuel mixture, as:

$\left(1-x_{H_{2}}\right) N H_{3}+x_{H_{2}} H_{2}+\frac{3-x_{H_{2}}}{4}\left(O_{2}+3.76 N_{2}\right) \rightarrow \ldots\left(\frac{3-x_{H_{2}}}{2}\right) H_{2} \mathrm{O}+\left(\frac{1-x_{H_{2}}}{2}+3.76 * \frac{3-x_{H_{2}}}{4}\right) N_{2}$

Non-stoichiometric mixtures are defined by the global equivalence ratio:

$$
\phi=\frac{\frac{X_{\mathrm{H}_{2}}+X_{\mathrm{NH}_{3}}}{X_{\text {air }}}}{\left(\frac{X_{\mathrm{H}_{2}}+X_{N H_{3}}}{X_{\text {air }}}\right)_{s t}}
$$

$X_{s}$ represents the molar fraction of the species, $s$, in the reactive mixture. The sparkignition timing was set to ensure the maximum net indicated mean effective pressure (IMEP) with a coefficient of variation of the IMEP over 100 cycles, $\mathrm{COV}_{\text {IMEP }}$ lower than $5 \%$. Only averaged values over 100 cycles were presented in this paper. The range of investigated operating conditions is summarized in Table 3. 
Table 3. Overview of the test conditions.

\begin{tabular}{cc}
\hline Engine Speed (rpm) & $\mathbf{6 5 0 ; ~ 1 0 0 0 ; ~ 1 5 0 0 ; ~ 2 0 0 0 ~}$ \\
\hline Intake temperature (K) & 323 \\
\hline Intake pressure (bar) & {$[0.6-1] 1.3$ for dilution impact } \\
\hline $\mathrm{H}_{2}$ molar fraction in the fuel, $x_{H_{2}}$ & {$[0.0-0.10]$} \\
\hline$\phi$ & {$[0.9-1.1]$} \\
\hline$\% \mathrm{~N}_{2}$ dilution & Up to $8 \%$ of the total at the intake \\
\hline
\end{tabular}

\section{Results}

\subsection{Operating Limits}

In Table 4, stable operation modes were identified with a cross and black cells indicate conditions where either ignition or stable operation $\left(\mathrm{COV}_{\text {IMEP }}<=5 \%\right)$ were possible. As can be seen, the addition of $10 \% \mathrm{H}_{2}$ was sufficient to promote the ignition in all conditions. Increasing the engine speed makes the combustion for pure ammonia more difficult. Besides, it was not possible to ignite or ensure stable operations at $2000 \mathrm{rpm}$ for pure ammonia. It was also more difficult to obtain stable combustion in lean conditions.

Table 4. Limits in operating the engine with ammonia for several engine speeds, equivalence ratios, percentages of $\mathrm{H}_{2}$ as a function of intake pressures.

\begin{tabular}{|c|c|c|c|c|c|c|c|c|c|c|c|c|c|}
\hline \multirow[b]{3}{*}{$\Phi$} & \multirow[b]{3}{*}{$P_{\text {in }}($ bar $)$} & \multicolumn{3}{|c|}{$650 \mathrm{rpm}$} & \multicolumn{3}{|c|}{$1000 \mathrm{rpm}$} & \multicolumn{3}{|c|}{$1500 \mathrm{rpm}$} & \multicolumn{3}{|c|}{$2000 \mathrm{rpm}$} \\
\hline & & \multicolumn{12}{|c|}{$\% \mathrm{H}_{2}$} \\
\hline & & $0 \%$ & $5 \%$ & $10 \%$ & $0 \%$ & $5 \%$ & $10 \%$ & $0 \%$ & $5 \%$ & $10 \%$ & $0 \%$ & $5 \%$ & $10 \%$ \\
\hline \multirow{3}{*}{0.9} & $<=0.65$ & & & $x$ & & & $x$ & & & $x$ & & & $x$ \\
\hline & $0.8-0.85$ & & $x$ & $x$ & $x$ & $x$ & $x$ & & $x$ & $x$ & & & $x$ \\
\hline & 1 & & $x$ & $x$ & $x$ & $x$ & $X$ & $x$ & $x$ & $x$ & & $x$ & $x$ \\
\hline \multirow{3}{*}{1} & $<=0.65$ & & & $x$ & & $x$ & $x$ & & & $x$ & & & $x$ \\
\hline & $0.8-0.85$ & $x$ & $x$ & $x$ & $X$ & $x$ & $x$ & & $X$ & $x$ & & $X$ & $x$ \\
\hline & 1 & $x$ & $x$ & $x$ & $x$ & $x$ & $x$ & $x$ & $x$ & $x$ & & $x$ & $x$ \\
\hline \multirow{3}{*}{1.1} & $<=0.65$ & & & $X$ & & $X$ & $X$ & & & $X$ & & & $X$ \\
\hline & $0.8-0.85$ & $x$ & $x$ & $X$ & $x$ & $X$ & $X$ & & $x$ & $X$ & & $x$ & $x$ \\
\hline & 1 & $x$ & $x$ & $x$ & $x$ & $x$ & $x$ & $x$ & $x$ & $x$ & & $x$ & $x$ \\
\hline
\end{tabular}

Figure 2 shows the IMEP as a function of the minimum intake pressure acceptable to ensure stable operation, i.e., $\mathrm{COV}_{\text {IMEP }}<=5 \%$. Increasing $\mathrm{H}_{2}$ content in the fuel enables to operate at lower intake pressure down to $0.55 \mathrm{bar}$, which provides a $2.75 \mathrm{Bar}$ IMEP. For pure ammonia, the minimum intake pressure achieved was 0.75 bar, corresponding to 4.8 bar IMEP. It was, therefore, possible to operate the engine at low load.

\subsection{Engine Performance as a Function of Regime}

Figure 3a shows the IMEP as a function of the engine speed for $10 \% \mathrm{H}_{2}$ in the fuel, which guarantees stable operations in all conditions. One can notice the classical IMEP increase with engine speed at optimized Spark-Timing [31] due to improved combustion, less wall heat losses, and improved volumetric efficiency. Higher IMEP was obtained for stoichiometric and slightly rich mixture due to higher energy content. It seems that the IMEP peak value was not reached on this engine speed range consistently with the work of Cornelius et al. [9] that show the peak IMEP at $2500 \mathrm{rpm}$ with a very similar CR. The indicated efficiency was around $28 \%$ for $650 \mathrm{rpm}$ up to $35 \%$ for $2000 \mathrm{rpm}$ for stoichiometric mixture. Ignition timing (IT) and Combustion phasing (CAX $=$ Crank Angle Degrees, 
CAD, when $X \%$ of fresh fuel mass is burned) at the stoichiometric condition with $5 \% \mathrm{H}_{2}$ in ammonia blend are plotted in Figure $3 \mathrm{~b}$. Similar combustion phasing and durations were displayed except for $2000 \mathrm{rpm}$, which had a much earlier spark timing. This phasing was set because of a very low flame speed compared to the engine speed: the flame required, therefore, more $\mathrm{CAD}$ to propagate in the cylinder.

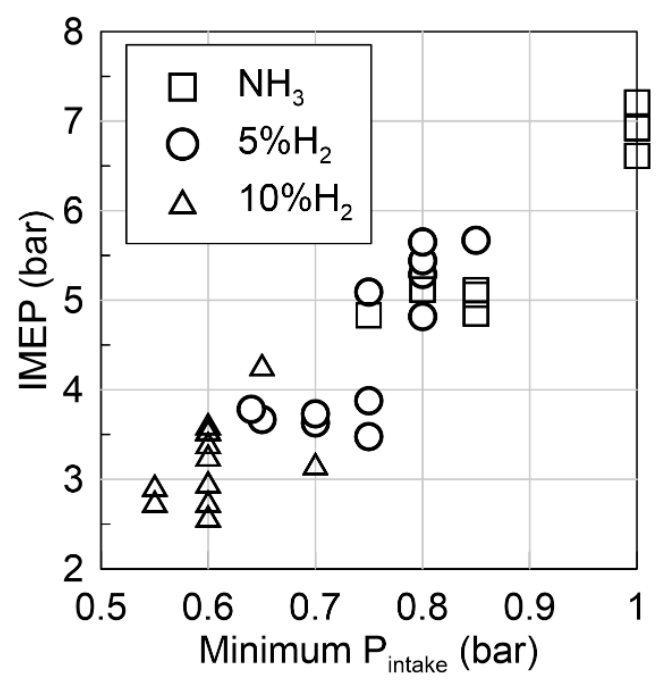

Figure 2. IMEP vs minimum intake Pressure.

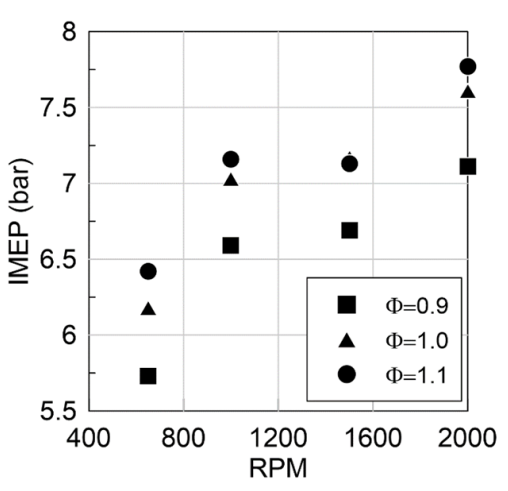

(a)

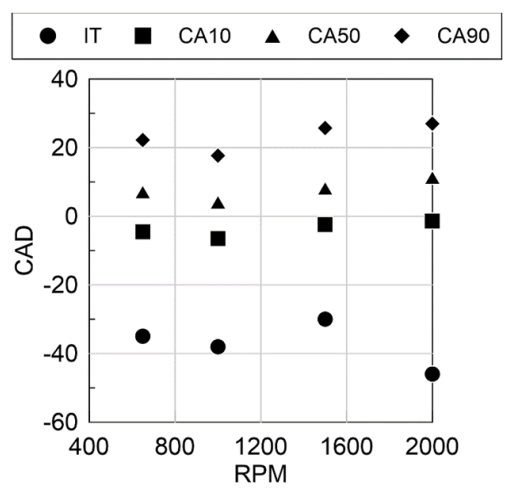

(b)

Figure 3. $\operatorname{IMEP}(\mathbf{a})$ and combustion phasing (b) vs. engine speed at $\mathrm{P}_{\mathrm{in}}=1$ bar and $10 \% \mathrm{H}_{2}(\Phi=1)$. 1500 rpm from [23].

Figure 4 presents $\mathrm{NOx}$ and $\mathrm{NH}_{3}$ emissions for three equivalence ratios and engine speeds for all $\mathrm{H}_{2}$ contents at atmospheric intake pressure. The maximum of $\mathrm{NOx}$ and $\mathrm{NH}_{3}$ correspond to $15 \mathrm{~g} / \mathrm{kWh}$ and $36 \mathrm{~g} / \mathrm{kWh}$, respectively, for 7 bars of IMEP. This maximum value of NOx, reached in lean air/fuel mixture, was about three times the level obtained with an engine fueled with gasoline. As expected, $\mathrm{NH}_{3}$ at exhaust increased with equivalence ratio when $\mathrm{NOx}$ decreases. The addition of $\mathrm{H}_{2}$ in ammonia induces an $\mathrm{NH}_{3}$ emission decrease at the exhaust, due to less $\mathrm{NH}_{3}$ as fuel at the intake, as expected, but also a slight improvement of the combustion efficiency, as for example, from 0.95 for neat ammonia to 0.96 with $10 \% \mathrm{H}_{2}$ at the stoichiometry at $1000 \mathrm{rpm}$. The maximum NOx level was found in this study at $\Phi=0.9$ for all conditions. The decrease of NOx with equivalence ratio increase, as previously observed [23-25], was similar to NOx evolution for any hydrocarbons even if the NOx pathway was not only the thermal one. Indeed, there was also the fuel NO route due to the presence of $\mathrm{N}$ in the fuel molecule itself. This increased NOx level at the exhaust. Increasing the engine speed seemed to reduce $\mathrm{NH}_{3}$ level, but the effect on $\mathrm{NOx}$ was less evident. In their study, Frigo and Gentili [28] showed that the NOx level was almost constant as a function as the engine speed from 2500 to $4000 \mathrm{rpm}$, but it should be 
kept in mind that $\mathrm{NH}_{3} / \mathrm{H}_{2}$ ratio was optimized for each operating condition. Here, $\mathrm{NOx}$ increased globally with both engine speed and $\% \mathrm{H}_{2}$ increase even if the engine speed effect was not so evident.

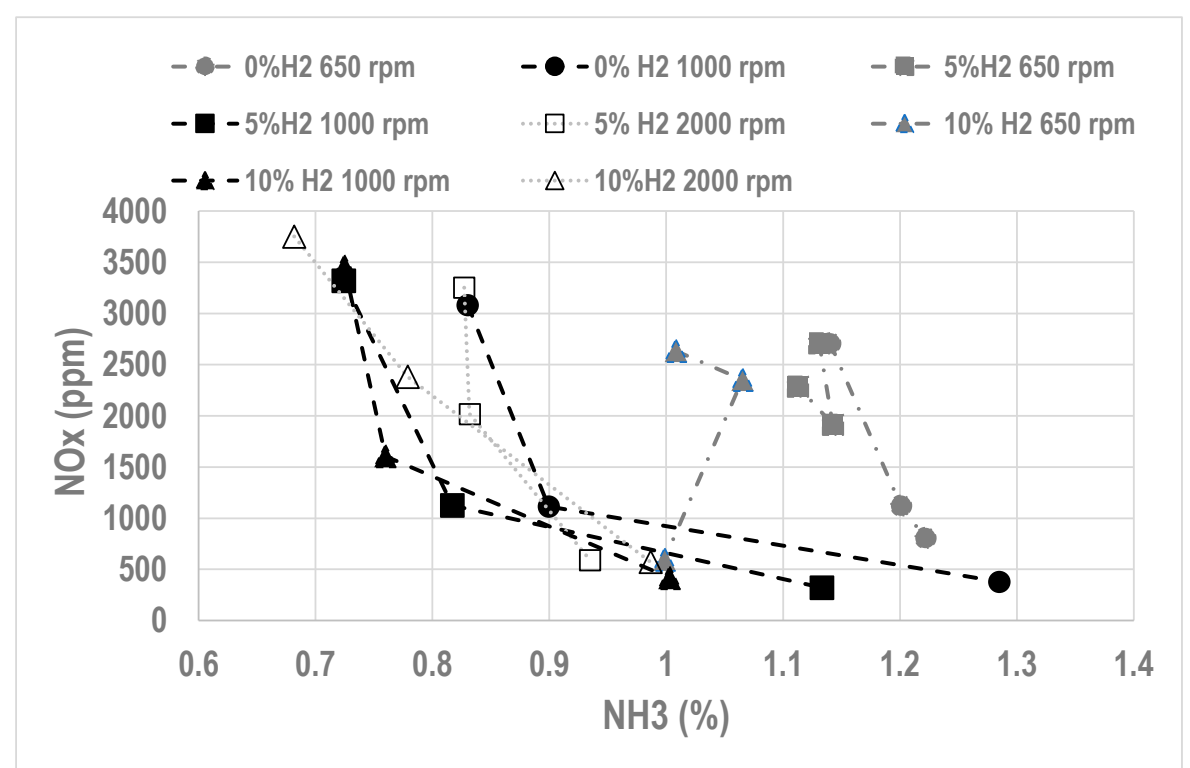

Figure 4. NOx emissions vs NH3 emissions for \%H2 content (0.5 and 10), 3 engine speeds and equivalence ratio. $\mathrm{P}_{\text {in }}=1$ bar.

The plot of $\mathrm{NO}_{2} / \mathrm{NO}$ in Figure 5 indicates that NOx emissions were mainly composed of $\mathrm{NO}$ for lean and stoichiometric conditions. Minimum levels of $\mathrm{NO}_{2}$ were obtained at stoichiometry for 650 (about 20 ppm) and $2000 \mathrm{rpm}$ (about $90 \mathrm{ppm}$ ). However, the highest values were measured at $1000 \mathrm{rpm}$ (i.e., between 300 and $500 \mathrm{ppm}$ ) without any expected explanations. Increasing equivalence ratio decreased $\mathrm{NO}_{2}$ but less than for $\mathrm{NO}$, thus increasing the proportion of $\mathrm{NO}_{2}$ in the NOx.

The combustion of $\mathrm{NH}_{3}$, due to the combustion kinetics and the presence of $\mathrm{N}$ in the fuel, can generate another product, $\mathrm{N}_{2} \mathrm{O}$, which has a higher global warming potential than $\mathrm{CO}_{2}$ itself (i.e., 265 times higher). The evolution of $\mathrm{N}_{2} \mathrm{O}$ as a function of the equivalence ratio, plotted in Figure 6, presents the same trend as NOx emissions: the peak value was reached on the lean side, and the equivalence ratio increase induced emission decrease. For example, by considering an stoichiometric air/fuel mixture, as example at $1000 \mathrm{rpm}$, $30 \mathrm{ppm}$ of $\mathrm{N}_{2} \mathrm{O}$ corresponded to $0.87 \%$ of $\mathrm{CO}_{2}$ as equivalent global warming impact, which represents $10 \%$ of $\mathrm{CO}_{2}$ emissions level for same engine fueling with an iso-octane/air stoichiometric mixture. It can also be noted that the increase of engine speed clearly increased $\mathrm{N}_{2} \mathrm{O}$ emissions (by 1.5), and the increase of $\mathrm{H}_{2}$ content seemed to also favor the production of $\mathrm{N}_{2} \mathrm{O}$. As a result, the potential of $\mathrm{NH}_{3}$ as fuel in decreasing greenhouse gases emissions is here illustrated. 


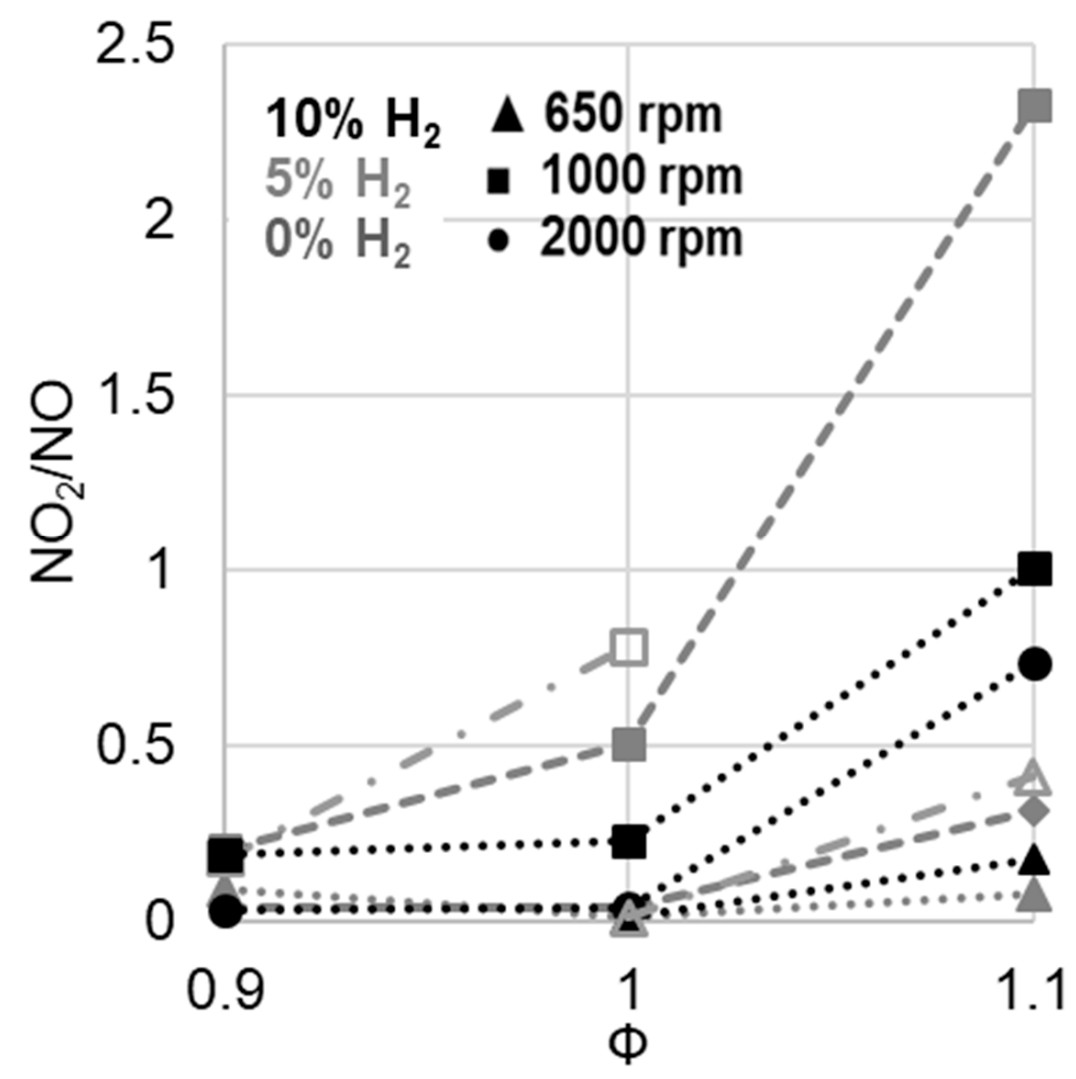

Figure 5. $\mathrm{NO}_{2} / \mathrm{NO}$ emissions vs equivalence ratio for different engine speeds and $\mathrm{H}_{2}$ content, $\mathrm{P}_{\text {in }}=1$ bar.

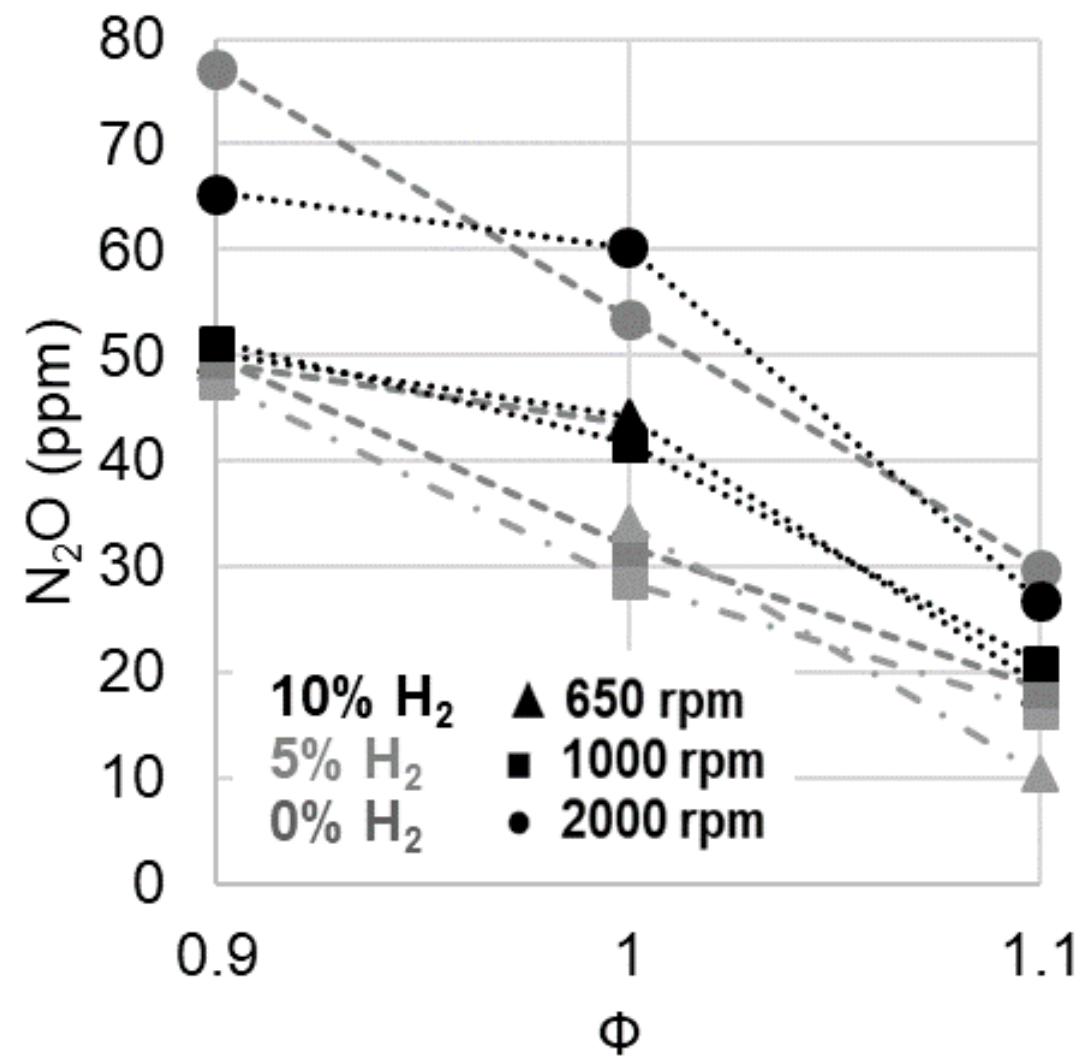

Figure 6. $\mathrm{N}_{2} \mathrm{O}$ emissions vs equivalence ratio for different engine speeds and $\mathrm{H}_{2}$ content, $\mathrm{P}_{\text {in }}=1$ bar. 
Due to the presence of $\mathrm{H}_{2}$ in some fuel blends but also to the local possible ammonia decomposition in the cylinder during the combustion phase, it was interesting to also follow $\mathrm{H}_{2}$ emissions, as displayed in Figure 7. As expected, $\mathrm{H}_{2}$ reaches an important level as unburnt gases of the fuel mixture up to $3 \%$ of total exhaust gases, in the case of rich fuel mixtures even for neat ammonia combustion. In that, in rich conditions, $\mathrm{H}_{2}$ emissions were even higher for ammonia only than for $\mathrm{NH}_{3}-\mathrm{H}_{2}$ blend. This was in agreement with the work of Cornelius et al. [9] and Lhuillier et al. [24]. In the case of lean and stoichiometric conditions, since the measured values were below the accuracy range of the analyzer, it indicated the total consumption of $\mathrm{H}_{2}$ as in $[9,24]$. The increase of engine speed seemed to lead to an increase of $\mathrm{H}_{2}$ emissions.

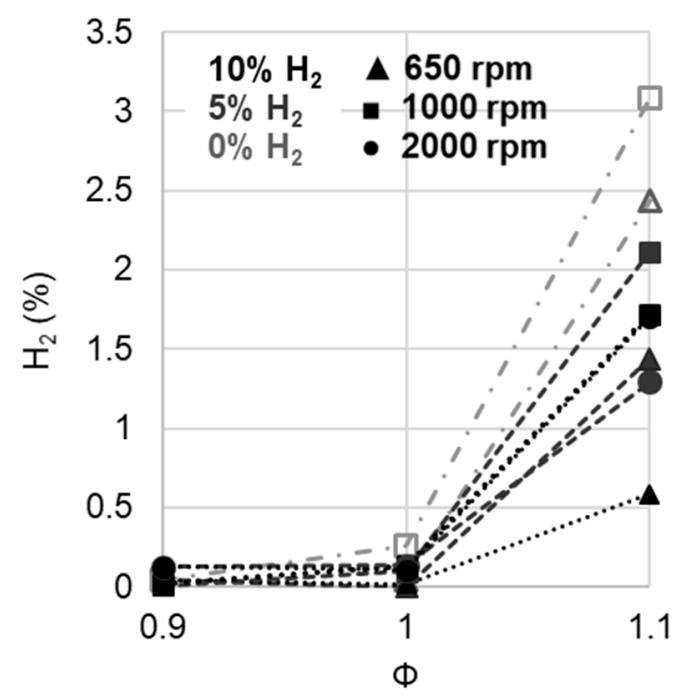

Figure 7. $\mathrm{H}_{2}$ emissions vs equivalence ratio for different engine speeds and $\mathrm{H}_{2}$ content in the fuel. Pin $=1$ bar.

From the exhaust pollutants measurement, mitigation strategies for both $\mathrm{NH}_{3}$ and NOx were needed before considering ammonia as a fuel, acceptable for real applications. A Selective Catalyst Reactor (SCR) could be one solution since both heat and the NOx reducing agent, $\mathrm{NH}_{3}$ was available in the exhaust pipe, as suggested by Westlye et al. [17]. It has to be noticed first that $\mathrm{NH}_{3}$ content in the exhaust was for all conditions higher than NOx to allow SCR operating. The feasibility of that approach was assessed in Figure 8 where the average exhaust temperature is plotted as a function of the equivalence ratio. The highest exhaust temperatures were obtained for stoichiometric and slightly rich mixtures, where the maximum LBV was reached, thus bringing the operating conditions closer to an ideal cycle. As the optimum operating temperature for usual catalysts was in the range $280-480{ }^{\circ} \mathrm{C}$, its correct operation has to be questioned at high speed and load. In the other hand, it has to be noted that the $\mathrm{H}_{2}$ content in the fuel (in the range studied) seems to have no impact on the exhaust temperature consistently with Lhuillier et al. results [23]. 


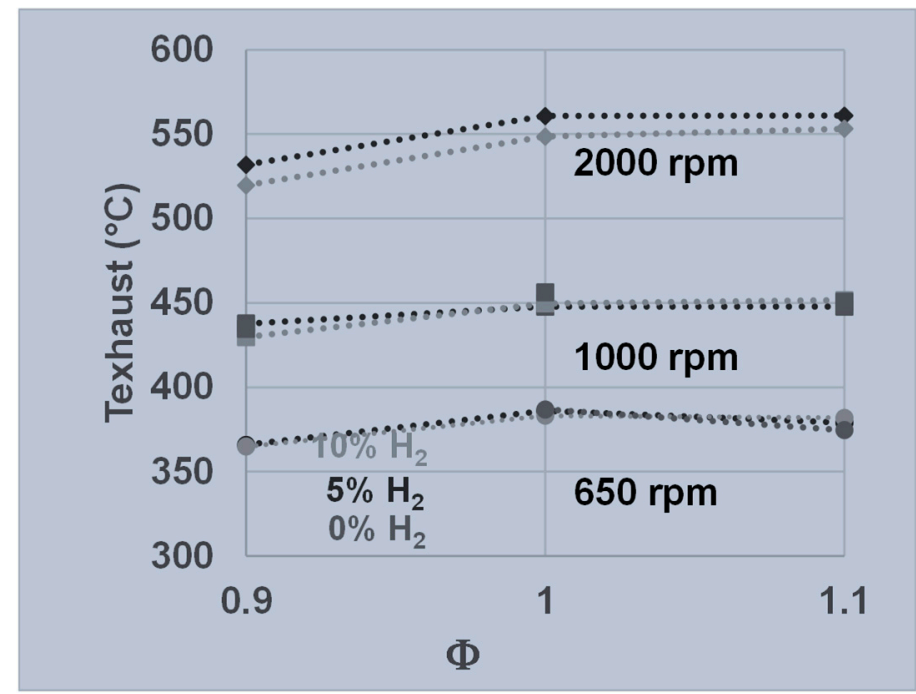

Figure 8. Exhaust temperature vs equivalence ratio. $\mathrm{P}_{\text {in }}=1$ bar.

Nonetheless, before considering complicated post-exhaust systems, the use of exhaust gases recirculation (internal or external) can be explored for two main reasons: to limit NOx emissions, especially for lean operating mode, but also to improve the combustion development itself for rich ammonia/air mixture due to the addition of some small $\mathrm{H}_{2}$ contents in the exhaust gases. In the following, a dilution with $\mathrm{N}_{2}$ is considered only to evaluate how it could be one actuator to reduce NOx emissions without affecting the stability of the combustion itself in the case of pure ammonia (without any $\mathrm{H}_{2}$ content at the intake).

\subsection{Dilution Opportunity @ 1500 rpm and $P_{\text {in }}=1.3$ Bar}

In order to simulate EGR, $\mathrm{N}_{2}$ was introduced at the intake in the case of ammonia as fuel only, for an intake pressure of 1.3 bar [25]. It was possible to ignite the air- $\mathrm{NH}_{3}-\mathrm{N}_{2}$ mixture up to $\mathrm{N}_{2}$ amount of $9 \%$ of the total intake air-fuel mixture, which corresponds to maximum $11 \%$ of intake air as an equivalent EGR. As shown in Figure 9, IMEP linearly decreases with $\% \mathrm{~N}_{2}$ (because of the lower energy content) up to $6-7 \% \mathrm{~N}_{2}$ where a drop occurs due to the stability limit that is reached as seen on the $\mathrm{COV}_{\text {IMEP }}$.

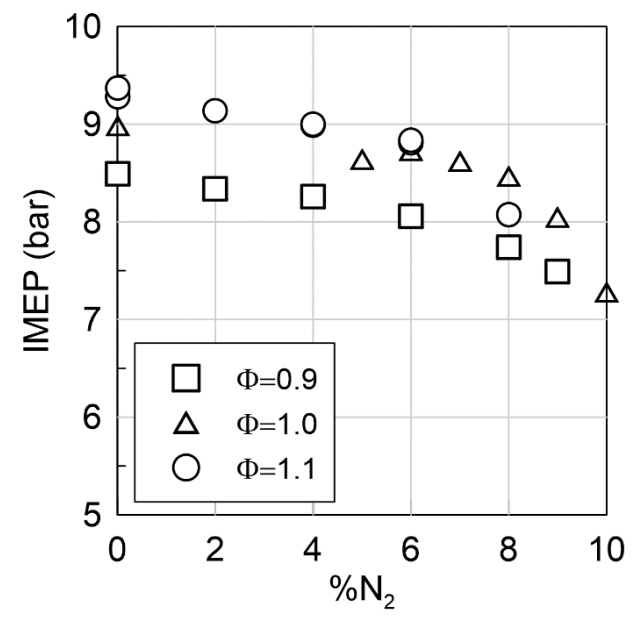

(a)

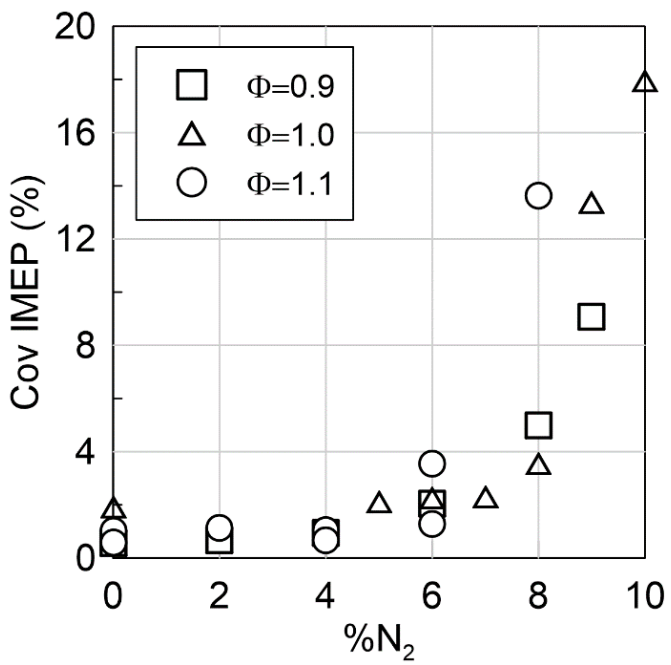

(b)

Figure 9. IMEP (a) and COV IMEP (b) vs $\% \mathrm{~N}_{2}$ in total intake gases for pure ammonia, $\mathrm{P}_{\text {in }}=1.3 \mathrm{bar}$, $1500 \mathrm{rpm}$. 
As expected, the combustion remains stable up to a certain percentage before $\mathrm{COV}_{\text {IMEP }}$ explodes (about $8 \% \mathrm{~N}_{2}$ ) similar to hydrocarbon fuel [32]. Dilution shows interesting potential in reducing NOx at the exhaust, as it can be seen in Figure 10, especially on the lean side where a $40 \%$ decrease was observed with $8 \% \mathrm{~N}_{2}$ without increasing $\mathrm{NH}_{3}$ emissions. Real EGR could be even more interesting since it should contain unburned $\mathrm{NH}_{3}$ as well as potential $\mathrm{H}_{2}$ as seen above and in [24].

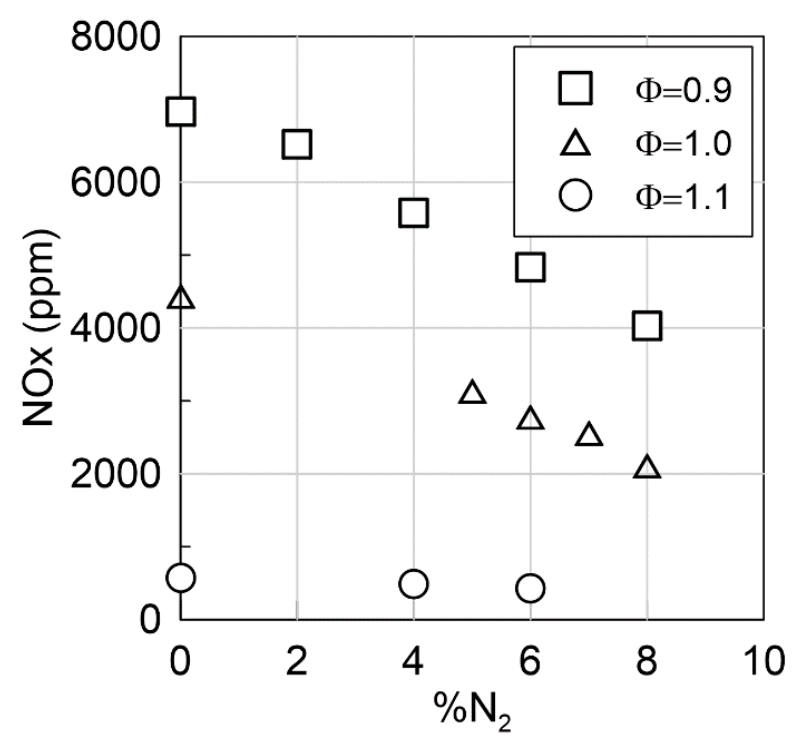

Figure 10. NOx vs. $\% \mathrm{~N}_{2}$ in total intake gases for pure ammonia. $\mathrm{P}_{\text {in }}=1.3 \mathrm{bar}, 1500 \mathrm{rpm}$.

\section{Conclusions}

This paper has provided insights into operating with ammonia in a current GDI SparkIgnition engine in terms of operating limit, engine speed effect, and dilution possibilities without any retrofit. Regarding the operating limits, it is clearly demonstrated that it is possible to run one engine at very low load as 2.75 bar IMEP, but when $10 \% \mathrm{H}_{2}$ is added. On the other hand, the low loads can also be obtained at the idle speed (i.e., $650 \mathrm{rpm}$ ) even with neat ammonia as fuel. Globally, $10 \% \mathrm{H}_{2}$ in the fuel guarantees all operating conditions possible. However, for neat ammonia, the low load operation is difficult with the compression ratio of 10.5 , requiring a greater minimum intake pressure. The operation at $2000 \mathrm{rpm}$ is also not possible due to the specific slow combustion speed of ammonia/air mixture. Combustion phasing appears to be not affected by the engine speed, but the ignition timing needs to be advanced for higher engine speed to guarantee sufficient time for the flame to propagate inside the cylinder.

Regarding the emissions, $\mathrm{NH}_{3}$ at the exhaust decreases with an engine speed increase, with highest levels reached for rich mixture. $\mathrm{NH}_{3}$ emissions for the leanest mixture (0.9) can reach $1 \%$ in vol, certainly due to the crevice trap. NOx emissions are mainly composed by $\mathrm{NO}$ and the effect of the engine speed seems to depend on the equivalence ratio. Even if $\mathrm{NH}_{3}$ does not produce any carbon content at the exhaust, it can emit $\mathrm{N}_{2} \mathrm{O}$, one of the strongest greenhouse gases. Due to its very low emission level, the global warming potential represents only $2 \%$ equivalent of $\mathrm{CO}_{2}$ impact. For both $\mathrm{NOx}$ and $\mathrm{N}_{2} \mathrm{O}$, the highest levels of emissions are observed on the lean side with a decrease with an equivalence ratio increase. Lastly, $\mathrm{H}_{2}$ is obtained at the exhaust in rich conditions even for neat ammonia combustion, indicating a local ammonia decomposition. Exhaust temperatures were also monitored and seemed suitable for SCR use to mitigate both $\mathrm{NH}_{3}$ and $\mathrm{NOx}$ emissions at least below $2000 \mathrm{rpm}$.

The last part of this study shows that dilution with $\mathrm{N}_{2}$ in turbocharged liked conditions is interesting in decreasing NOx at the exhaust, especially for lean and stoichiometric mixture even if only an equivalent EGR ratio lower than $10 \%$ is used to ensure combustion 
stability. As a result, there is interesting potential in studying operation with real EGR dilution as it should contain not only $\mathrm{N}_{2}$ and water but also $\mathrm{H}_{2}, \mathrm{NO}_{\mathrm{X}}$, and $\mathrm{NH}_{3}$ with surely an impact on the chemistry and the thermodynamics.

Author Contributions: Methodology, all authors; investigation, C.M.-R., P.B.; resources, all authors. All authors have read and agreed to the published version of the manuscript.

Funding: This project receives support from the European Union's Horizon 2020 research and innovation under grant agreement No. 862482 (ARENHA project).

Acknowledgments: The authors acknowledge the contribution of B. Raitière and J. Bouriot, from joint PRISME/PSA Open lab 'Energetics', for their technical support.

Conflicts of Interest: The authors declare no conflict of interest.

\section{References}

1. Valera-Medina, A.; Xiao, H.; Owen-Jones, M.; David, W.I.F.; Bowen, P.J. Ammonia for power. Prog. Energy Combust. Sci. 2018, 69, 63-102. [CrossRef]

2. Valera-Medina, A.; Amer-Hatem, F.; Azad, A.K.; Dedoussi, I.C.; de Joannon, M.; Fernandes, R.X.; Glarborg, P.; Hashemi, H.; He, X.; Mashruk, S.; et al. Review on Ammonia as a Potential Fuel: From Synthesis to Economics. Energy Fuels 2021, 35, 6964-7029. [CrossRef]

3. AWijayanta, A.T.; Oda, T.; Purnomo, C.W.; Kashiwagi, T.; Aziz, M. Liquid hydrogen, methylcyclohexane, and ammonia as potential hydrogen storage: Comparison review. Int. J. Hydrog. Energy 2019, 44, 15026-15044. [CrossRef]

4. Linstrom, P.J.; Mallard, W.G. NIST Chemistry WebBook, NIST Standard Reference Database Number 69, 20899; National Institute of Standards and Technology: Gaithersburg, MD, USA, 2018. [CrossRef]

5. Mørch, C.; Bjerre, A.; Gøttrup, M.; Sorenson, S.; Schramm, J. Ammonia/hydrogen mixtures in an SI-engine: Engine performance and analysis of a proposed fuel system. Fuel 2011, 90, 854-864. [CrossRef]

6. Bicer, Y.; Dincer, I. Life cycle assessment of ammonia utilization in city transportation and power generation. J. Clean. Prod. 2018, 170, 1594-1601. [CrossRef]

7. Koch, E. Ammonia as a fuel for motor buses. J. Inst. Pet. 1949, 31, $21-32$.

8. Gray, J.T.; Dimitroff, E.; Meckel, N.T.; Quillian, R.D. Ammonia Fuel-Engine Compatibility and Combustion. SAE Tech. Pap. 1966. [CrossRef]

9. Cornelius, W.; Huellmantel, L.W.; Mitchell, H.R. Ammonia as an Engine Fue. SAE Tech. Pap. 1965. [CrossRef]

10. Starkman, E.S.; Newhall, H.K.; Sutton, R.; Maguire, T.; Farbar, L. Ammonia as a Spark Ignition Engine Fuel: Theory and Application. SAE Tech. Pap. 1966. [CrossRef]

11. Starkman, E.S.; James, G.E.; Newhall, H.K. Ammonia as a Diesel Engine Fuel: Theory and Application. SAE Tech. Pap. 1967. [CrossRef]

12. TPearsall, J.; Garabedian, C.G. Combustion of Anhydrous Ammonia in Diesel Engines. SAE Tech. Pap. 1967. [CrossRef]

13. Sawyer, R.F.; Starkman, E.S.; Muzio, L.; Schmidt, W.L. Oxides of Nitrogen in the Combustion Products of an Ammonia Fueled Reciprocating Engine. SAE Tech. Pap. 1968. [CrossRef]

14. Garabedian, C.; Johnson, J. The Theory of Operation of an Ammonia Burning Internal Combustion Engine, Report 634681; MI, USA, 1965. Available online: https:/ /apps.dtic.mil/sti/citations/AD0634681 (accessed on 7 July 2021).

15. Dimitriou, P.; Javaid, R. A review of ammonia as a compression ignition engine fuel. Int. J. Hydrog. Energy 2020, 45, 7098-7118. [CrossRef]

16. Mounaïm-Rousselle, C.; Brequigny, P. Ammonia as Fuel for Low-Carbon Spark-Ignition Engines of Tomorrow's Passenger Cars. Front. Mech. Eng. 2020, 6, 70. [CrossRef]

17. Westlye, F.R.; Ivarsson, A.; Schramm, J. Experimental investigation of nitrogen based emissions from an ammonia fueled SI-engine. Fuel 2013, 111, 239-247. [CrossRef]

18. Grannell, S.M.; Assanis, D.N.; Bohac, S.V.; Gillespie, D.E. The Fuel Mix Limits and Efficiency of a Stoichiometric, Ammonia, and Gasoline Dual Fueled Spark Ignition Engine. J. Eng. Gas Turbines Power 2008, 130, 042802. [CrossRef]

19. Grannell, S.M.; Assanis, D.N.; Gillespie, D.E.; Bohac, S.V. Exhaust Emissions From a Stoichiometric, Ammonia and Gasoline Dual Fueled Spark Ignition Engine. In Proceedings of the ASME International Combustion Engine Division 2009 Spring Tech. Conf., Milwaukee, WI, USA, 3-6 May 2009. [CrossRef]

20. Ryu, K.; Zacharakis-Jutz, G.E.; Kong, S.-C. Performance enhancement of ammonia-fueled engine by using dissociation catalyst for hydrogen generation. Int. J. Hydrog. Energy 2014, 39, 2390-2398. [CrossRef]

21. Ryu, K.; Zacharakis-Jutz, G.E.; Kong, S.-C. Effects of gaseous ammonia direct injection on performance characteristics of a spark-ignition engine. Appl. Energy 2014, 116, 206-215. [CrossRef]

22. Koike, M.; Miyagawa, H.; Suzuoki, T.; Ogasawara, K. Ammonia as a hydrogen energy carrier and its application to internal combustion engines. In Sustainable Vehicle Technologies; Warwickshire, G., Ed.; Woodhead Publishing: Cambridge, UK; pp. 61-70. [CrossRef] 
23. Lhuillier, C.; Brequigny, P.; Contino, F.; Mounaïm-Rousselle, C. Experimental study on ammonia/hydrogen/air combustion in spark ignition engine conditions. Fuel 2020, 269, 117448. [CrossRef]

24. Lhuillier, C.; Brequigny, P.; Contino, F.; Rousselle, C. Performance and Emissions of an Ammonia-Fueled SI Engine with Hydrogen Enrichment. SAE Tech. Pap. 2019. [CrossRef]

25. Lhuillier, C.; Brequigny, P.; Contino, F.; Rousselle, C. Combustion Characteristics of Ammonia in a Modern Spark-Ignition Engine. SAE Tech. Pap. 2019. [CrossRef]

26. Woo, Y.; Jang, J.Y.; Lee, Y.J.; Kim, J.N. Recent progress on the Ammonia-Gasoline and the Ammonia-Diesel Dual Fueled Internal Combustion Engines in Korea. In Proceedings of the 11th Annual $\mathrm{NH}_{3}$ Fuel Conferences, Des Moines, IA, USA, 22 September 2014.

27. Haputhanthri, S.O.; Maxwell, T.T.; Fleming, J.; Austin, C. Ammonia and Gasoline Fuel Blends for Spark Ignited Internal Combustion Engines. J. Energy Resour. Technol. 2015, 137, 062201. [CrossRef]

28. Frigo, S.; Gentili, R. Analysis of the behaviour of a 4-stroke Si engine fuelled with ammonia and hydrogen. Int. J. Hydrog. Energy 2013, 38, 1607-1615. [CrossRef]

29. Comotti, M.; Frigo, S. Hydrogen generation system for ammonia-hydrogen fuelled internal combustion engines. Int. J. Hydrog. Energy 2015, 40, 10673-10686. [CrossRef]

30. Lhuillier, C.; Brequigny, P.; Lamoureux, N.; Contino, F.; Mounaïm-Rousselle, C. Experimental investigation on laminar burning velocities of ammonia/hydrogen/air mixtures at elevated temperatures. Fuel 2020, 263, 116653. [CrossRef]

31. Heywood, J.B. Internal Combustion Engine Fundamentals, 2nd ed.; McGraw-Hill Education: New York, NY, USA, 2018. Available online: https:/ / www.accessengineeringlibrary.com/content/book/9781260116106 (accessed on 7 July 2021).

32. Francqueville, L.; Michel, J.-B. On the Effects of EGR on Spark-Ignited Gasoline Combustion at High Load. SAE Int. J. Engines 2014, 7, 1808-1823. [CrossRef] 